\title{
Modulation of Monocyte Activation in Patients with Rheumatoid Arthritis by Leukapheresis Therapy
}

\author{
Gabriele Hahn, Bruno Stuhlmüller, Norbert Hain, Joachim R. Kalden, Klaus Pfizenmaier, ${ }^{*}$ and Gerd R. Burmester \\ Institute of Clinical Immunology and Rheumatology, Department of Medicine III, University of Erlangen-Nuremberg, DW-8520
}

Erlangen; and * Institute of Cell Biology and Immunology, University of Stuttgart, DW-7000 Stuttgart, Federal Republic of Germany

\begin{abstract}
One of the hallmarks in rheumatoid arthritis (RA) is the intense activation of the monocyte-macrophage system. In the present investigation, the modulation of blood monocyte activation was studied with regard to the secretion of cytokines and inflammatory mediators, and to the expression of cytokine receptors. Patients with severe active RA underwent repeated leukapheresis procedures that removed all circulating monocytes. Highly enriched monocyte preparations from the first and third leukapheresis were studied. There were striking differences between these two monocyte populations. Cells obtained from the first leukapheresis constitutively released large amounts of prostaglandin $\mathrm{E}_{2}\left(\mathrm{PGE}_{2}\right)$, neopterin, interleukin $1 \beta$ (IL-1 $\beta)$ and tumor necrosis factor- $\alpha$ (TNF- $\alpha)$. In particular, IL-1 $\beta$ and neopterin production were further enhanced by stimulation with either interferon- $\gamma($ IFN- $\gamma)$ or $\mathrm{TNF}-\alpha$ without a synergistic effect. In contrast, cells derived from the third leukapheresis procedure showed a close to normal activation status with only low levels of cytokine and mediator production as well as a reduced response to cytokine stimulation. The number of the receptors for IFN- $\gamma$ and TNF- $\alpha$ was not changed between first and third leukapheresis. However, TNF-binding capacity was only detectable upon acid treatment of freshly isolated monocytes. A further upregulation was noted upon $24 \mathrm{~h}$ in vitro culture, suggesting occupation of membrane receptors and receptor down-regulation by endogenously produced TNF- $\alpha$. Northern blot analysis of cytokine gene expression was in good correlation with the amount of mediators determined on the protein level. These data indicate that cells of the monocytemacrophage system are already highly activated in the peripheral blood in RA patients with active disease. These cells can be efficiently removed by repeated leukapheresis and are replenished by monocytes that have, with respect to cytokine and mediator production, a considerably lower activation status. ( $J$. Clin. Invest. 1993. 91:862-870.) Key words: cytokines • leukapheresis - monocyte activation - neopterin - rheumatoid arthritis
\end{abstract}

\section{Introduction}

The rheumatoid synovium is characterized by the infiltration with activated macrophages which form a major part of the

Address reprint requests to Dr. Gerd R. Burmester, Department of Medicine III, University of Erlangen-Nuremberg, Krankenhausstrasse 12, DW-8520 Erlangen, Federal Republic of Germany.

Received for publication 2 July 1992 and in revised form 25 September 1992.

J. Clin. Invest.

(C) The American Society for Clinical Investigation, Inc.

0021-9738/93/03/0862/09 \$2.00

Volume 91, March 1993, 862-870 destructive pannus tissue $(1,2)$. Not only tissue macrophages, but also blood monocytes show an elevated activation status. These cells already spontaneously produce large amounts of prostanoids and interleukin 1 (IL-1) (3). Furthermore, an increased phagocytic activity of monocytes has been demonstrated (4). Possible factors leading to monocyte/macrophage activation are immune complexes, notably those containing rheumatoid factors $(5,6)$, but also several major cytokines have been implicated in the pathogenesis of rheumatoid arthritis such as interferon- $\gamma$ (IFN- $\gamma$ ), tumor necrosis factor- $\alpha$ (TNF- $\alpha$ ), and colony-stimulating factors $(7,8)$.

Neopterin, a pyrimidine derivative, has been found to be elevated in patients suffering from certain types of cancer and viral diseases, but also in individuals with rheumatoid arthritis (RA) (9-11). Whenever the T lymphocyte-macrophage axis is activated, an increase in neopterin production is to be expected. Neopterins are synthesized in vivo from guanosine triphosphate cyclohydrolase (9). Macrophages differ from lymphocytes in that they lack enzymes for the synthesis of tetrahydrobiopterin $(9,10)$, so that they are only able to produce dihydroneopterin. This compound cannot be further metabolized by these cells and can subsequently be easily detected in body fluids and culture supernatants. In vivo levels of neopterin rise whenever cellular immunity is activated. Thus, elevated serum and urine levels of neopterin are highly sensitive markers of the activation of the monocyte/macrophage system.

The objective of the present investigation was to study mechanisms of activation of rheumatoid monocytes as well as to monitor a possible modulation in the course of leukapheresis therapy analyzing the production of inflammatory mediators and cytokines. To this end, patients with severe RA underwent repeated leukapheresis procedures which removed not only circulating lymphocytes, but also all blood monocytes at a given time $(12,13)$. It has long been puzzling why leukapheresis is an efficient therapy in certain patients long before there is a measurable decrease in the number of peripheral blood lymphocytes (14). We report here that leukapheresis efficiently removes activated monocytes from the blood stream, and that the repopulating cells show a reduced activation status as compared with pretherapy levels. These findings may in part explain the clinical benefits induced by leukapheresis treatment, which has been demonstrated in previous studies.

\section{Methods}

\section{Patient population}

The total patient population consisted of 10 individuals ( 5 male and 5 female; mean age $55 \mathrm{yr}$ ) with severe RA as diagnosed according to the

1. Abbreviations used in this paper: LAF, lymphocyte-activating factor; $\mathrm{MC}$, median channel; TNF, tumor necrosis factor. 
American College of Rheumatology criteria (15). All had highly active disease according to the following test results ( mean $\pm \mathrm{SD}$ ): a sedimentation rate of $73 \pm 33 \mathrm{~mm} / \mathrm{h}$, a C-reactive protein level of $72 \pm 27 \mathrm{mg} /$ liter, and a high Ritchie articular index (16) of $93 \pm 25$. With the exception of one individual (D.C.), all patients were rheumatoid factor positive with a mean value of $90 \mathrm{IU} / \mathrm{ml}$ in the Waaler-Rose assay. Except for patient D.C., who suffered from a longstanding arthritis, all patients had a disease of recent onset ( $<5 \mathrm{yr})$ and had not been treated with remission inducing or immunosuppressive agents. None of the patients received steroids. Before each leukapheresis procedure nonsteroidal anti-inflammatory drugs had been withdrawn for at least $12 \mathrm{~h}$. Patients were not treated with antirheumatic agents with a half-life of more than $6 \mathrm{~h}$. In general, three leukapheresis procedures were performed in 2- or 3-d intervals. Materials from the first and third leukapheresis were taken for examination. Immediately at the end of leukapheresis therapy, treatment with remission inducing drugs was started (gold salts or methotrexate). Concomitant clinical assessments revealed a reduction of the mean Ritchie articular index from $93 \pm 25$ down to $59 \pm 14$ after the final leukapheresis procedure $(P<0.01$, paired $t$ test $)$.

\section{Leukapheresis procedure}

Leukapheresis was performed using a Baxter/Travenol cell separating system (CS-2000; Baxter Healthcare Corp., Deerfield, IL) according to the manufacturer's information. As calculated from the differential blood count, $1-2 \times 10^{9}$ monocytes were removed during each run, which was approximately equal to the circulating pool of monocytes (17). There were no differences in absolute monocyte counts before the first and the third leukapheresis $(680 \pm 231$ vs. $689 \pm 475$ monocytes $/ \mu \mathrm{l}$ ). For control experiments, peripheral blood monocytes obtained by a single leukapheresis from healthy donors were used. In two additional patients with RA synovial tissue cells obtained from material derived from joint surgery were investigated.

\section{Cell separation}

Peripheral blood cells of leukapheresis material were first applied to a Ficoll-Hypaque gradient to obtain the mononuclear cell fraction. Subsequently, monocytes were enriched by a two step Percoll-Gradient (Percoll, Biochrom, Berlin, FRG) using $51 \%(d=0.573 \mathrm{~g} / \mathrm{ml})$ Percoll in the first and $48 \%(d=0.539 \mathrm{~g} / \mathrm{ml})$ Percoll in the second step. The few remaining $\mathrm{T}$ cells were removed by an E-rosetting procedure, as described elsewhere (18). The purity of the monocyte population was $95 \%$ on an average as determined by conventional May-GrünewaldGiemsa staining. There were no significant differences between the purity of monocyte preparations derived from first or third leukapheresis.

Synovial tissue mononuclear cells were eluted from surgical specimens from patients with rheumatoid arthritis undergoing selective joint surgery. Synovial tissue fragments were generated by fine scissors, and mononuclear cells were obtained after DNAse/collagenase digestion by density gradient centrifugation as described previously (19).

\section{Immunofluorescence studies}

The evaluation of mononuclear cell populations and the monocyte subset was performed by indirect immunofluorescence using flow cytometry with an Epics Profile cell analyzer (Coulter Corp., Hialeah, FL) (20). The following reagents were employed: T cell-specific antibodies against the CD3 antigen (OKT3 [21]), anti-B cell, anti-monocyte or anti-HLA-DR reagents (CD75 [22]; CD14 [23]; HLA-DR [20]) used to analyze mononuclear cells, and finally the IFN- $\gamma$ receptor-specific antibody A6C5 (24).

\section{Cytokines}

For the stimulation of monocytes we used recombinant IFN- $\gamma$ (sp act 2 $\left.\times 10^{7} \mathrm{U} / \mathrm{mg}\right)$ and TNF- $\alpha\left(\right.$ sp act $\left.5 \times 10^{7} \mathrm{U} / \mathrm{mg}\right)$, all initially generated by Genentech, Inc., San Francisco, CA, and kindly provided by Dr. G. Adolf, Boehringer Ingelheim, Vienna, Austria.

\section{Cell cultures}

Blood monocytes and synovial tissue mononuclear cells were incubated in RPMI 1640 (Gibco Laboratories, Grand Island, NY) supplemented with $1 \%$ of penicillin/streptomycin $\left(10^{4} \mathrm{U} / \mathrm{ml}\right)$, Hepes buffer (Carl Roth KG, Karlsruhe, FRG), and $10 \%$ of fetal calf serum (Gibco). This culture medium did not contain detectable levels of endotoxin $(<2 \mathrm{ng} / \mathrm{ml}$ as determined by the E-Toxate assay, Sigma Chemical Co., Deisenhofen, FRG). Initial kinetic studies had revealed maximum secretions in culture for the different cytokines or mediators analyzed at the following time points: TNF- $\alpha$ (day 1 ), $\mathrm{PGE}_{2}$ (day 1 to 3 ), IL-1 $\beta$ (day 3 ), neopterin (day 5 ). Therefore, culture supernatants were harvested and further investigated after these periods throughout the subsequent experiments.

\section{Cytokine assays}

Interleukin-1. IL-1 was determined by an IL-1 $\beta$-specific and two-site directed ELISA established by Dr. Christiane-Rordorf-Adam (Ciba Geigy, Basel, Switzerland ) with an exclusion limit of $8 \mathrm{pg} / \mathrm{ml}$ for IL- $1 \beta$ $(25,26)$ as well as the lymphocyte-activating factor (LAF) bioassay (kindly performed by Dr. U. Feige, Ciba-Geigy). For the LAF assay, thymuses of 4-6 wk-old $\mathrm{C} 3 \mathrm{H} / \mathrm{HeJ}$ mice were excised avoiding any contamination with blood. Single-cell suspensions of thymocytes were prepared in culture medium (mentioned above) containing $10 \%$ heatinactivated FCS. $5 \times 10^{5}$ thymocytes per well were plated in 96-well microtiterplates in $0.2-\mathrm{ml}$ vol. $2 \mu \mathrm{g} / \mathrm{ml}$ of PHA (Difco Co., Detroit, $\mathrm{MI})$ and the IL-1 containing culture supernatants as well as an IL-1 standard (Biogen, Geneva, Switzerland) diluted from 1:2 to 1:256 were added to a final volume of $0.2 \mathrm{ml}$. After $3 \mathrm{~d}$ of incubation under standard conditions $\left(37^{\circ} \mathrm{C}, 5 \% \mathrm{CO}_{2}\right)$, cultures were pulsed with $2 \mu \mathrm{Ci}$ of $\left[{ }^{3} \mathrm{H}\right]$ thymidine (Amersham Corp., Braunschweig, FRG), harvested 4 $\mathrm{h}$ later and counted for $\beta$-emission. The addition of antibodies to IL-1$\alpha$ and IL- $1 \beta$ (Ciba-Geigy) had demonstrated, that $>80 \%$ of the IL- 1 activity determined in the thymocyte assay was attributable to IL- $1 \beta$ (data not shown). Therefore, bioactive IL-1 levels were calculated from the ratio of the $\mathrm{ED}_{50}$ of dose-response curves of an IL- $1 \beta$ standard.

$T N F-\alpha$. TNF- $\alpha$ was determined in a TNF- $\alpha$ ELISA obtained from Medgenix, Diagnostics, Brussels, which is a solid-phase enzyme-amplified sensitivity immunoassay. $200 \mu$ l of each standard $(0,15,50,150$, $500,1,500 \mathrm{pg} / \mathrm{ml}$ ), control and sample, were dispensed into the wells of a the 96-well microtiter plate. Subsequently, $50 \mu \mathrm{l}$ of incubation buffer (Tris-Maleate buffer with BSA and preservatives) was dispensed into each well and the microtiter plate was incubated for $2 \mathrm{~h}$ at room temperature on a horizontal shaker. After washing three times with an ELISA washer $100 \mu \mathrm{l}$ of standard 0 and $50 \mu \mathrm{l}$ of anti-TNF horseradish peroxidase conjugate (in Tris-Maleate buffer with BSA and preservatives) were dispensed into all wells, and the microtiter plate was incubated for $2 \mathrm{~h}$ at room temperature with continuous shaking. After a second round of three washings, $200 \mu$ l of the freshly prepared revelation solution (tetramethylbenzidine in substrate buffer $\mathrm{H}_{2} \mathrm{O}_{2}$ in acetate/citrate buffer) was dispensed into each well. After incubation for $30 \mathrm{~min}$ at room temperature with continuous shaking, $50 \mu \mathrm{l}$ of stopping reagent $\left(\mathrm{H}_{2} \mathrm{SO}_{4}\right)$ was put into each well. The absorbance was read at $450 \mathrm{~nm}$ with a photometer, and a calibration curve was constructed using all standard points for which absorbances were $<1.5 \mathrm{OD}$ unit.

$P G E_{2}$. The antibodies to $\mathrm{PGE}_{2}$ were a kind gift of Margot Reinke (Institute of Pharmacology and Toxicology, Erlangen, FRG). The specimens were incubated with a defined quantity of ${ }^{3} \mathrm{H}$-labeled $\mathrm{PGE}_{2}$ (Amersham Corp.) and antibodies to $\mathrm{PGE}_{2}$ - adjusted to a maximal binding of $40 \%$ of the radioactively labeled $\mathrm{PGE}_{2}$ used-in PBS-gelatine $(0.1 \%)$ for at least $3 \mathrm{~h}$ at $4{ }^{\circ} \mathrm{C}$. To eliminate unbound $\mathrm{PGE}_{2}$, activated carbon (3\%) was added. After centrifugation at $1,800 \mathrm{~g}$ for 10 min at $4{ }^{\circ} \mathrm{C},{ }^{3} \mathrm{H}$-labeled $\mathrm{PGE}_{2}$ was determined in decanted supernatants.

Neopterin. The samples were incubated in the dark with a defined quantity of an antiserum against neopterin for $1 \mathrm{~h}$. Subsequently, 100 $\mu \mathrm{l}$ of a radioactive tracer [ $\left.{ }^{125} \mathrm{~J}\right]$ neopterin (Hennig, Berlin) were added, and the samples were incubated in the dark for $1 \mathrm{~h}$ at $20^{\circ} \mathrm{C}$. Finally, 
$2 \mathrm{ml}$ of 65 -polyethyleneglycol were added to all samples. After centrifugation at $200 \mathrm{~g}$ for $10 \mathrm{~min}$, the supernatant was removed and the radioactivity of the pellet was measured in a gamma-counter (Minaxi- $\gamma$, Packard Instruments, Inc., Downers Grove, IL).

\section{$I F N-\gamma$ and $T N F-\alpha$ binding studies}

Binding assays and Scatchard plot analysis of specific IFN- $\gamma$ and TNF$\alpha$ binding were performed as described with iodinated recombinant IFN- $\gamma$ and TNF- $\alpha$, respectively, labeled by the chloramine-T method to high specific radioactivity $(20-40 \mu \mathrm{Ci} / \mu \mathrm{g})$ under retention of bioactivity essentially as described $(18,27,28)$. All binding assays were performed in triplicates with $2 \times 10^{6}$ monocytes per tube. Nonspecific binding was determined in the presence of a 250 -fold excess of the respective unlabeled cytokine. Analyses of binding data were performed with the program ENZFITTER (Biosoft, Elsevier) and are presented as receptors per cell.

\section{Northern blot analysis}

Monocytes were obtained from the leukapheresis material of healthy donors and a highly active RA patient. Cells were enriched by the procedures described above. Approximately 1-2.5 $\times 10^{8}$ cells were lysed in $6 \mathrm{M}$ guanidinium thiocyanate. Subsequently, the lysates were layered onto a $5.7 \mathrm{M} \mathrm{CsCl}$ cushion and centrifuged as described by Chirgwin et al. (29). Total RNA from each fraction was quantified by spectrophotometer analysis (Uvikon 810; Kontron Instruments, Milan, Italy) at $260 \mathrm{~nm}$ and adjusted to $200 \mu \mathrm{g} / 100 \mu \mathrm{l}$. Equivalent amounts of mRNA were determined by slot-blot analysis using a radioactively random primed $\gamma$-actin cDNA probe. Total RNA samples were run on a $1.2 \%$ agarose (Gibco)/formaldehyde gel. Transfer of RNA to membranes (Stratagene, Heidelberg; Flash) was performed overnight by $20 \times$ SSC capillary blotting. The membranes were washed in $6 \times$ SSC and dryed on air. RNAs were fixed by ultraviolet-autocrosslinking (UV Stratalinker 1800; Stratagene). The blots were hybridized overnight at $42^{\circ} \mathrm{C}$ as described (30) with radioactively random primed (Gibco) cDNA inserts coding for IL- $1 \beta$, TNF- $\alpha$ and $\gamma$-actin. The blots were washed in $2 \times$ SSC containing $0.1 \%$ SDS for 20 and $30 \mathrm{~min}$ in $0.2 \times$ SSC $/ 0.1 \%$ SDS. Finally, the blots were autoradiographed at $-70^{\circ} \mathrm{C}$ using intensifying screens. Analyses of the relative areas of the bands detected after autoradiography were performed using an LKB Ultrascan XL enhanced laser densitometer (LKB Produkter, Bromma, Sweden) using the software provided by the manufacturer.

\section{Results}

Activation of peripheral blood monocytes and synovial tissue macrophages by TNF- $\alpha$ and IFN- $\gamma$ in vitro. As outlined above, neopterin is one of the most sensitive markers to study the activation of the monocyte/macrophage system. Therefore, the production of this marker was studied in monocytes/ macrophages of various origins. The data obtained demonstrate that in contrast to normal donors, inflammatory blood monocytes and synovial macrophages were able to produce large amounts of neopterin without intentional in vitro stimulation (Fig. 1 and Table I). In both cell populations, this activity was further enhanced by TNF- $\alpha$ and in particular by IFN- $\gamma$ treatment. When applied in combination, an additive effect was seen in two out of three patients, but no synergistic effect of TNF- $\alpha$ and IFN- $\gamma$ was noted. This revealed a novel property of TNF- $\alpha$ to trigger the neopterin metabolism in purified monocytes/macrophages. Both constitutive and cytokine stimulated neopterin production was found to be approximately fivefold higher in inflammatory synovial tissue macrophages as compared to blood monocytes (Fig. 1).

In subsequent experiments, this analysis was extended to the production of $\mathrm{PGE}_{2}$ and IL- $1 \beta$ by normal and RA mono-

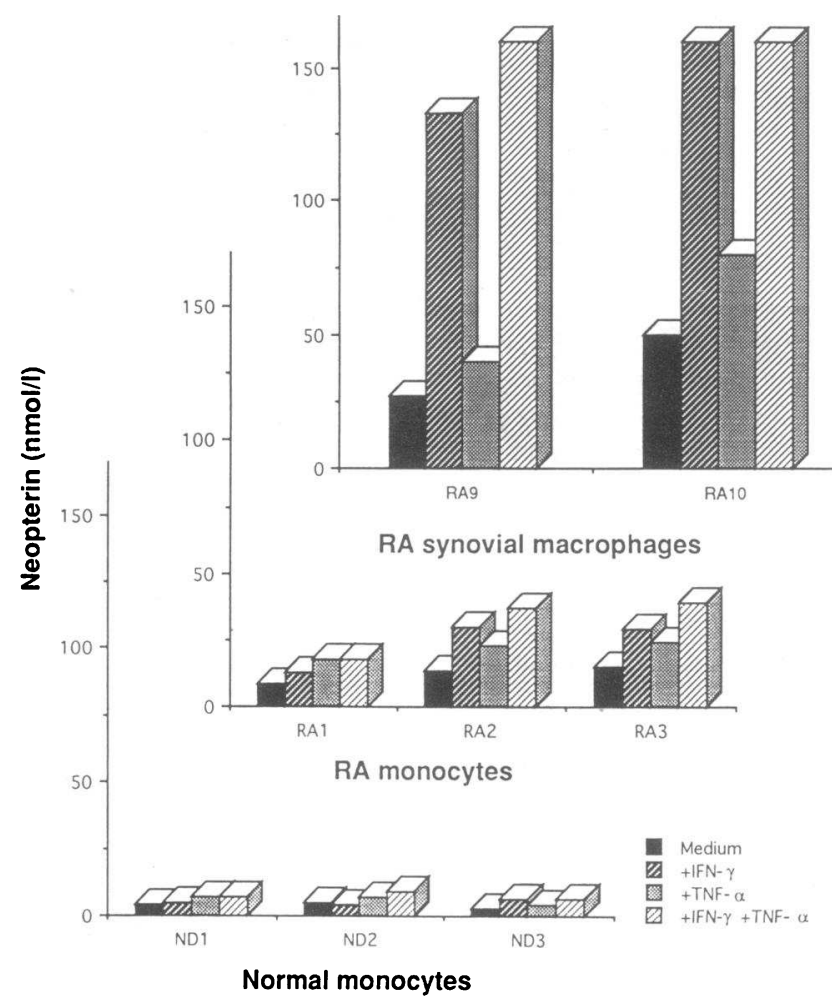

Figure 1. Secretion of neopterin (nmol/liter) into culture media derived from various monocyte/macrophage populations. $1 \times 10^{6} / \mathrm{ml}$ of peripheral blood monocytes from normal donors (ND 1-3) and RA patients $(R A l-3)$ as well as synovial tissue mononuclear cells ( $R A 9$ and $R A 10$ ) were cultured in various concentrations of recombinant IFN- $\gamma$ and/or TNF- $\alpha$ ranging from 1 to $100 \mathrm{U} / \mathrm{ml}$ for $5 \mathrm{~d}$. Maximum values of neopterin production are presented.

cytes. As demonstrated in Table I, monocytes from normal donors secreted only small amounts of $\mathrm{PGE}_{2}$, IL- $1 \beta$, and neopterin into the culture supernatants and were only poorly stimulated by exposure to IFN- $\gamma$ and TNF- $\alpha$. In contrast, untreated monocytes from RA patients exhibited high basal levels of these mediators which were even further enhanced by cytokine stimulation.

Depletion of activated monocytes by leukapheresis therapy. One objective of the present study was to monitor the state of activation of monocytes in the course of leukapheresis therapy. Based on the kinetic data available (17), it is likely that nearly all monocytes circulating in the peripheral blood are removed by a single leukapheresis procedure. In the experiments performed, peripheral blood monocytes from patients with severe RA were obtained from the first and third leukapheresis procedure and were cultured in vitro in the presence and absence of IFN- $\gamma$ and TNF- $\alpha$. Two patients with seropositive and seronegative disease were investigated in greater detail (Fig. 2, both parts). These experiments revealed that the monocytes from the first leukapheresis material spontaneously released large amounts of the inflammatory mediators $\mathrm{PGE}_{2}$, IL- $1 \beta$, TNF- $\alpha$, and neopterin. Upon in vitro treatment with IFN- $\gamma$ or TNF- $\alpha$, neopterin production was strongly increased in both patients, and IL-1 production was enhanced in one patient. In contrast, monocytes obtained from the third leukapheresis showed a markedly reduced spontaneous release of these mediators. Moreover, in monocytes from the third leukapheresis stimula- 
Table I. Production of $P G E_{2}, I L-1 \beta$, and Neopterin Induced by IFN- $\gamma$ and TNF- $\alpha$ in Blood Monocytes

from Normal Donors and Patients with $R A$

\begin{tabular}{|c|c|c|c|c|}
\hline & Nil & IFN- $\gamma$ & TNF- $\alpha$ & $\mathrm{IFN}-\gamma+\mathrm{TNF}-\alpha$ \\
\hline \multicolumn{5}{|c|}{$\mathrm{PGE}_{2}(n g / m l)$} \\
\hline $1 \mathrm{ND}$ & 9 & 23 & 10 & 12 \\
\hline $2 \mathrm{ND}$ & 10 & 16 & 12 & 16 \\
\hline $3 \mathrm{ND}$ & 19 & 16 & 14 & 26 \\
\hline 4 ND & 22 & 22 & 26 & 24 \\
\hline $1 \mathrm{RA}$ & 17 & 17 & 23 & 35 \\
\hline $2 \mathrm{RA}$ & 60 & 62 & 62 & 70 \\
\hline $3 \mathrm{RA}$ & 29 & 37 & 24 & 26 \\
\hline $4 \mathrm{RA}$ & 15 & 20 & 21 & nd \\
\hline \multicolumn{5}{|c|}{ IL-1 $\beta(p g / m l)$} \\
\hline 1 ND & 35 & 115 & 57 & 84 \\
\hline $2 \mathrm{ND}$ & 22 & 15 & 8 & 33 \\
\hline 3 ND & 16 & 17 & 15 & 44 \\
\hline $4 \mathrm{ND}$ & 15 & 17 & 40 & 8 \\
\hline $1 \mathrm{RA}$ & 254 & 789 & 576 & 727 \\
\hline $2 \mathrm{RA}$ & 256 & 396 & 524 & 388 \\
\hline $3 \mathrm{RA}$ & 320 & 447 & 401 & 418 \\
\hline $4 \mathrm{RA}$ & 195 & 301 & 104 & nd \\
\hline \multicolumn{5}{|c|}{ Neopterin (nmol/liter) } \\
\hline 1 ND & 5 & 5 & 7 & 7 \\
\hline $2 \mathrm{ND}$ & 5 & 4 & 7 & 9 \\
\hline 3 ND & 3 & 7 & 4 & 7 \\
\hline $4 \mathrm{ND}$ & 2 & 2 & 3 & 2 \\
\hline $1 \mathrm{RA}$ & 13 & 29 & 23 & 37 \\
\hline $2 \mathrm{RA}$ & 8 & 12 & 17 & 18 \\
\hline 3 RA & 15 & 29 & 24 & 39 \\
\hline $4 \mathrm{RA}$ & 20 & 39 & 16 & nd \\
\hline
\end{tabular}

$1 \times 10^{6} / \mathrm{ml}$ of peripheral blood monocytes were cultured in various concentrations of recombinant IFN- $\gamma$ and/or TNF- $\alpha$ ranging from 1 to $100 \mathrm{U} / \mathrm{ml}$ for $3 \mathrm{~d}$. Maximum values are presented.

tion with IFN- $\gamma$ and TNF- $\alpha$ resulted in only a marginally increased production of $\mathrm{PGE}_{2}$ and neopterin. Although IL-1 production was stimulated, the levels reached were well below those of unstimulated cells from the first leukapheresis material.

Similar data on the IL-1 production by RA monocytes were obtained in two additional RA patients. Again, a marked reduction of IL-1 secretion was seen (patients 3 and 4, Table IIA ). In a separate patient, IL-1 levels were determined by the LAF bioassay. Bioactive IL-1 was secreted in significantly higher amounts in material derived from the first vs. the third leukapheresis at all time points of monocyte cultures investigated confirming the ELISA findings observed in the other patients (data not shown). As demonstrated in Table IIA, repeated leukapheresis resulted in a reduction of bioactive IL-1 down to $17 \%$ of the initial levels.

In additional experiments, monocytes derived from three RA patients were phenotypically characterized by determining the expression of the CD14 and HLA-DR antigens. These studies showed a small, but consistant decrease in the expression of both surface molecules in the course of leukapheresis therapy (CD14: 82 $\pm 18 \%$ positive cells, median channel [MC] 100 \pm 14 in first leukapheresis vs. $60 \pm 23 \%$, MC $79 \pm 16$ in third leukapheresis; HLA-DR: $82 \pm 9 \%$, MC $96 \pm 18$ vs. $69 \pm 19 \%$, MC $89 \pm 19$ ).

Northern blot analyses. Monocytes obtained from leukapheresis material derived from normal blood donors and an additional highly active RA patient were used for total RNA preparation and Northern blot analysis of TNF- $\alpha$ and IL- $1 \beta$ gene expression. A $\gamma$-actin probe was used as a control to determine mRNA quantity. In parallel, RNA from the promyelocytic cell line HL-60 and from granulocytes obtained from the synovial fluid of an additional RA patient served as further controls. As shown in Fig. 3 and Table IIB, IL-1 $\beta$ ( $1.7 \mathrm{~kb})$ and TNF- $\alpha(1.6 \mathrm{~kb})$ mRNA levels were increased in RA monocytes derived from the first leukapheresis. In monocytes from the third leukapheresis, the IL- $1 \beta$ and TNF- $\alpha$ mRNA levels were highly reduced as determined by Laser scanning densitometry (IL- $1 \beta$ down to $22 \%$, and TNF- $\alpha$ down to $11.2 \%$ of the first leukapheresis levels after adjustment for mRNA levels as calculated using the $\gamma$-actin signal). They were thus comparable to those of normal donors (Table IIB). In RNA preparations from the HL- 60 cell line only small amounts of IL- $1 \beta$ mRNA were found, and no signal for TNF- $\alpha$ was revealed. In granulocytes neither IL- $1 \beta$ nor TNF- $\alpha$ mRNAs were detectable.

Expression of the receptors for IFN- $\gamma$ and $T N F-\alpha$ on monocytes. Cytokines initiate their various bioactivities by high affinity binding to specific cell surface receptors (31). Our previous studies had shown that in PBMC the IFN- $\gamma$ receptor is subjected to heterologous down-regulation by granulocyte/ macrophage colony-stimulating factor (18). In contrast to the constitutively expressed IFN- $\gamma$ receptor, expression of TNF receptors by peripheral blood lymphocytes has been shown to be activation dependent (32). The expression of TNF-receptors in peripheral blood monocytes at various stages of in vivo activation has not been studied so far. We have here investigated IFN- $\gamma$ and TNF- $\alpha$ receptor expression in monocytes and asked whether receptor levels were influenced by repeated leukapheresis. Sufficient material was available from two patients with RA. Scatchard plot analyses and immunofluorescence studies with receptor-specific antibodies revealed no changes in IFN- $\gamma$ receptor expression in both patients between the first and third leukapheresis (Table III). Similarly, specific TNF-binding capacity, determined in one patient after the first and third leukapheresis was not changed. Interestingly, TNF receptors ( 500 per cell) could only be revealed upon acid wash of monocytes, releasing potentially receptor-bound TNF- $\alpha$. Moreover, upon $24 \mathrm{~h}$ in vitro culture without intentional stimulation, a two- to fivefold increased TNF binding capacity was revealed in both patients ( Table III) suggesting up-regulation of TNF receptor expression.

\section{Discussion}

In RA the monocyte/macrophage system is strongly activated as documented by an increased production of inflammatory mediators (33-35), enhanced expression of Fc receptors (5) and an augmented phagocytic activity of monocytes (4). In the present investigation we studied the production of inflammatory mediators by monocytes and the possible modulation of their activity in patients suffering from severe RA. The following major points emerged from this study: $(a)$ Monocytes from RA patients with active disease spontaneously produce large 
A) PGE 2

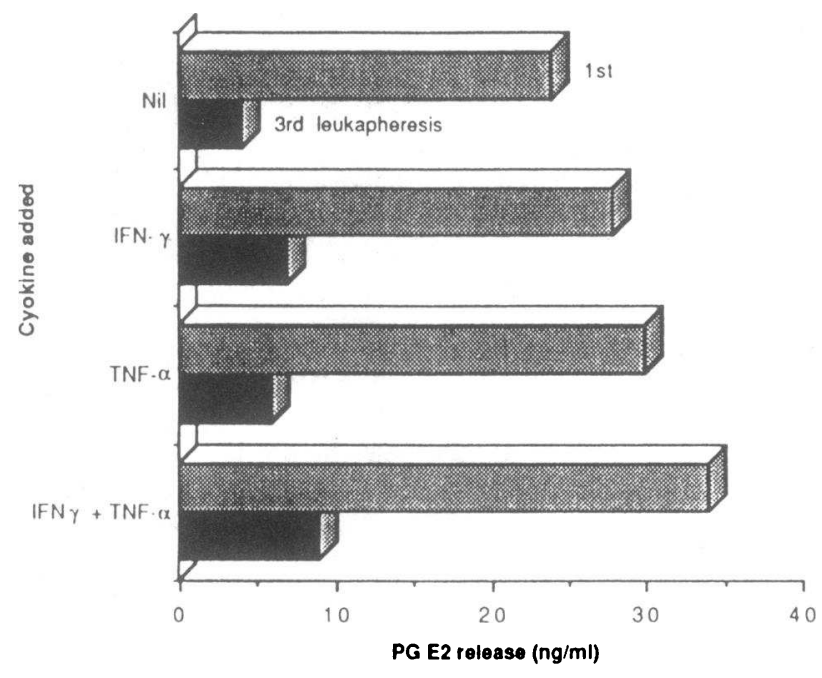

B) Neopterin

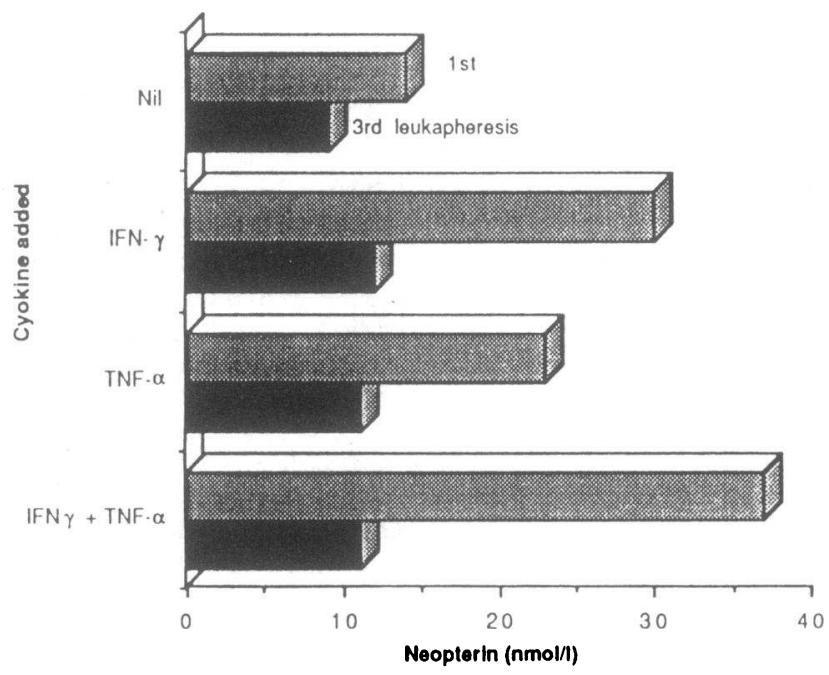

C) IL-1

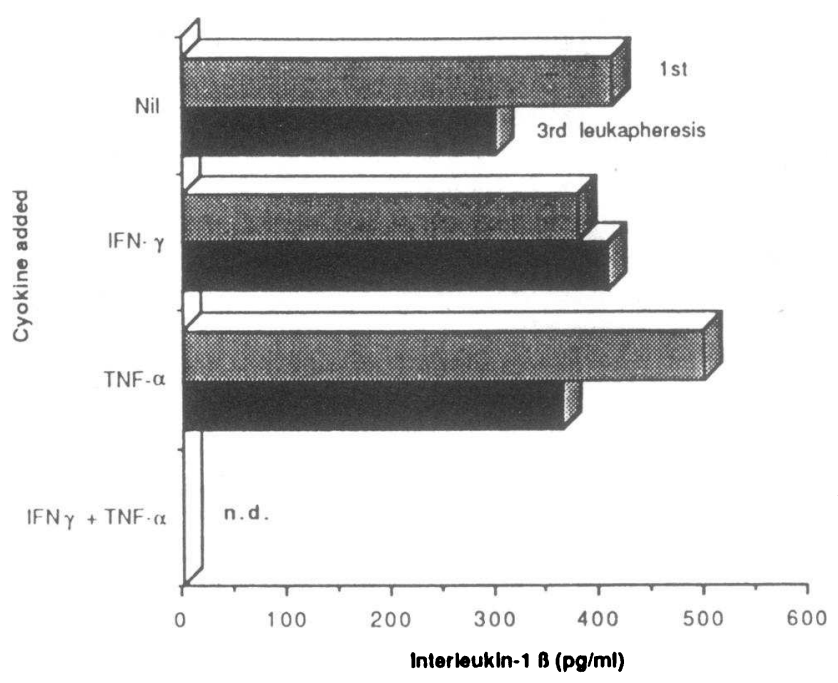

D) TNF- $\alpha$

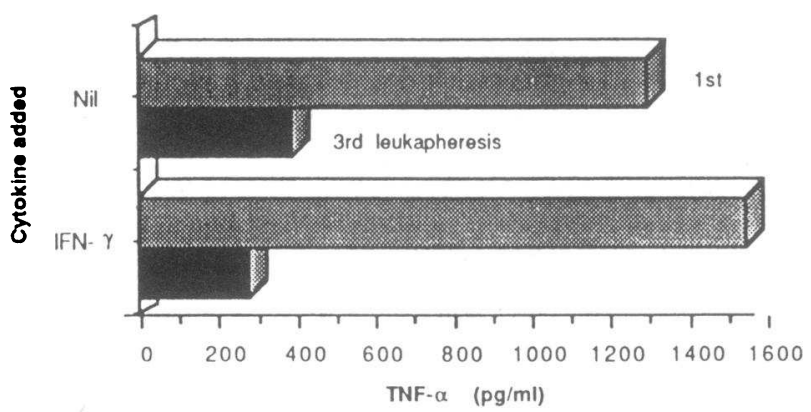

Figure 2. Production of $\mathrm{PGE}_{2}(\mathrm{ng} / \mathrm{ml}), \mathrm{IL}-1 \beta(\mathrm{pg} / \mathrm{ml})$, neopterin $(\mathrm{nmol} / \mathrm{l})$, and TNF- $\alpha(\mathrm{pg} / \mathrm{ml})$ by peripheral blood monocytes $\left(1 \times 10^{6} / \mathrm{ml}\right)$ from two RA patients (above: patient with seropositive disease; opposite page: patient with seronegative disease). Cells were obtained from the first and the third leukapheresis run and cultured in various concentrations of recombinant IFN- $\gamma$ and/or TNF- $\alpha$ ranging from 1 to $100 \mathrm{U} / \mathrm{ml}$ or medium alone for 1-5 days. Maximum values of the individual cultures are presented.

amounts of PGE 2 , IL- $1 \beta$, TNF- $\alpha$, and neopterin. An exceedingly high level of neopterin release was seen in synovial tissue macrophages. ( $b$ ) In most cases, the already elevated production of inflammatory markers could even be further enhanced by the addition of IFN- $\gamma$ and/or TNF- $\alpha$. Interestingly, these experiments revealed the novel property of TNF- $\alpha$ to enhance neopterin production by purified monocytes. $(c)$ The removal of the activated monocyte pool by leukapheresis led to the repopulation of the blood stream with cells showing a close to normal activation status as revealed by lower basal levels of mediator production and reduced responsiveness to cytokine stimulation. $(d)$ The changes in the response to the cytokines used were not due to a decrease of cytokine receptors on repopulating cells.

These findings strongly support the hypothesis that the monocyte-macrophage system plays a pivotal role in the pathogenesis of rheumatoid arthritis. We deliberately selected highly active patients for investigation to presumably obtain maximum levels of inflammatory markers. None of these patients was treated with steroids or immunosuppressive or remissioninducing drugs at the time of study, and nonsteroidal drugs had been discontinued in a time period which was ethically justifiable.

One particularly useful marker indicative of activation of the mononuclear phagocyte system proved to be neopterin. As mentioned above, in the human system this molecule is exclusively produced by monocytes and macrophages. This was also evident in our study where neither synovial tissue fibroblasts, endothelial cells, nor lymphocytes of blood or tissue origin produced detectable levels of neopterin (data not shown). Comprehensive studies by Wachter, Huber, and other investigators had already shown elevated levels in the serum, urin and synovial fluid in RA, strongly correlated to disease activity (36-40). The data obtained in the present investigation suggest that 
A) PGE

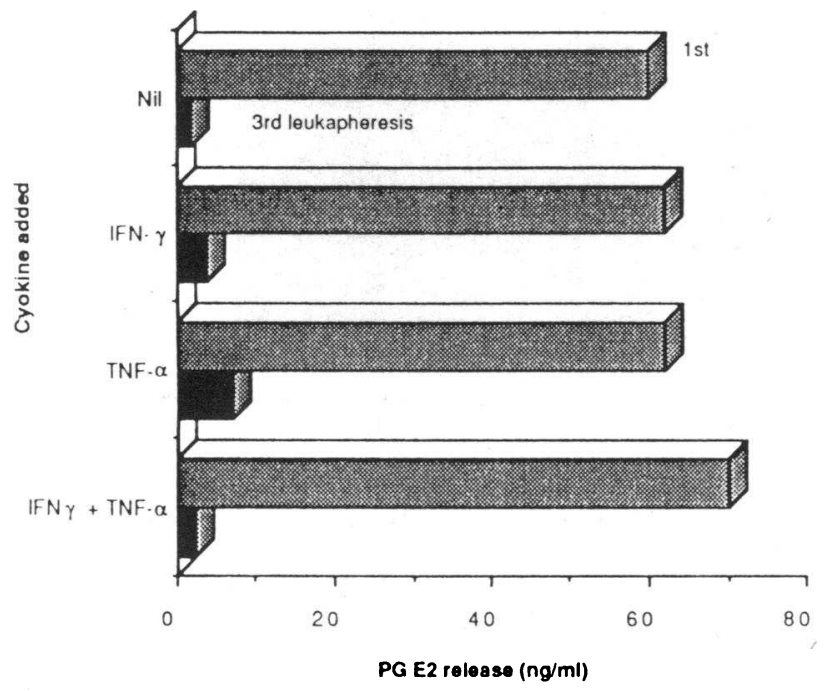

B) Neopterin

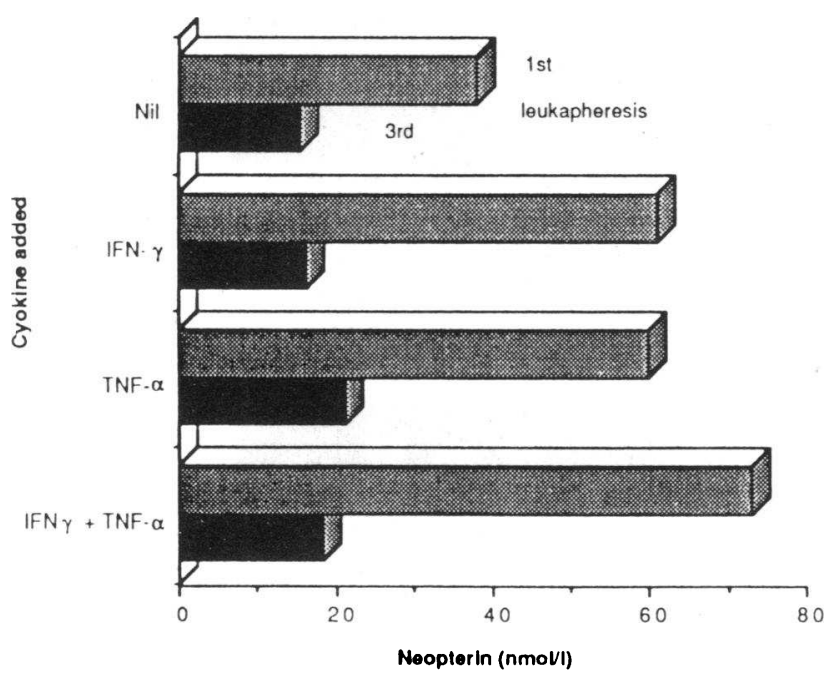

C) IL-1

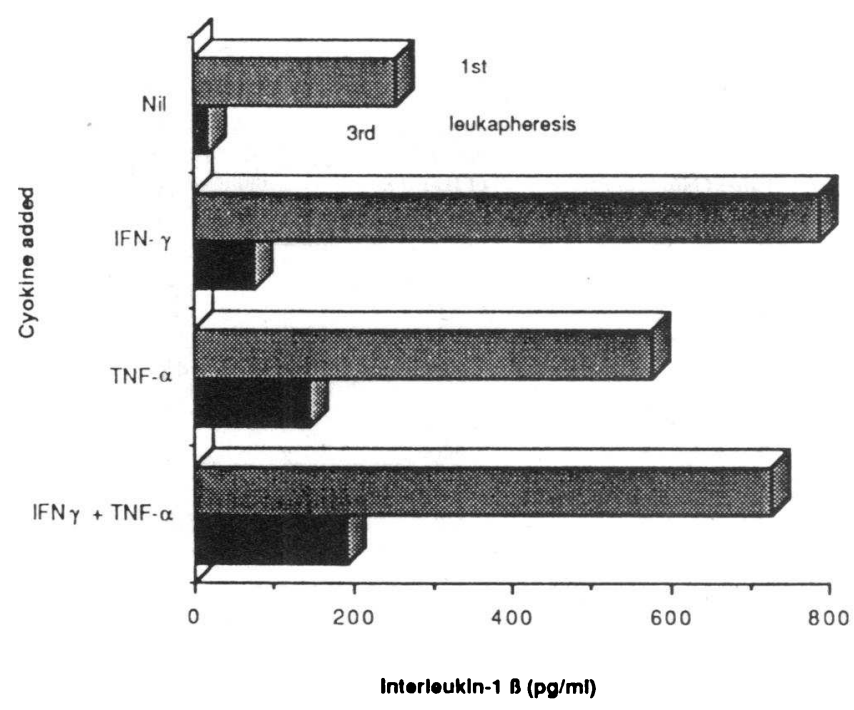

D) TNF- $\alpha$

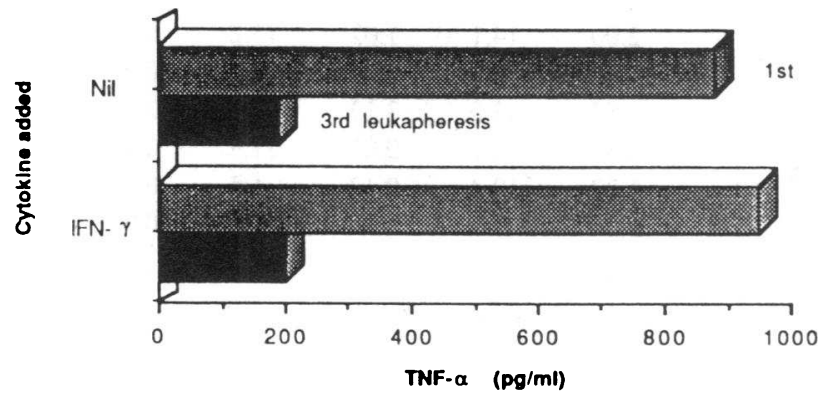

Figure 2 ( Continued)

blood monocytes and/or synovial macrophages may represent the main source of this inflammatory marker. Of particular interest was the exceedingly high production of neopterin by synovial tissue macrophages at levels that have not been reported previously for any other cell type. The signals that induce the secretion of neopterins in vivo have not yet been clearly identified. However, in vitro studies suggest that IFN- $\gamma$ is the most important, if not the only, inducer in monocytes derived from normal donors (39-41). We have shown that TNF- $\alpha$ is an alternative inductive signal for neopterin release by purified monocytes in an inflammatory situation. This appears to be particularly important since the tissue and blood levels of IFN- $\gamma$ in RA are very low (42), whereas significant amounts of TNF- $\alpha$ have been documented earlier (43) and in this study.

The design of the present investigation allowed to analyze the influence of leukapheresis on the monocyte system and its activation status. It had long been unexplained why the clinical response to leukapheresis already occurred after three proce- dures, long before there was a detectable change in mononuclear cell populations ( 14), a finding that was also confirmed in our patients. Our data indicate that the removal of activated monocytes by leukapheresis may contribute to the reduction of clinical disease activity. Thus, the activation status and the response to cytokines of blood monocytes was drastically altered by leukapheresis. Due to our study design, it was not possible to investigate how long it may take for monocyte activation to recur after leukapheresis in that immediately posttherapy immunosuppressive or gold salt treatment was started. Moreover, because leukapheresis had been discontinued, it was no longer possible to obtain sufficient numbers of highly purified monocytes. It is, however, very unlikely that the leukapheresis procedure itself influenced monocyte activation, since this was not evident in normal controls.

The results obtained in the present study demonstrate that monocytes repopulating the blood stream after leukapheresis show a close to normal activation status and thus suggest the hypothesis that they may be derived from fresh bone marrow 
Table II. Reduction of Cytokine Levels

by Leukapheresis Therapy in Patients with RA

\begin{tabular}{|c|c|c|c|c|c|c|}
\hline \multicolumn{7}{|c|}{ A. Reduced production of IL-1 as determined by ELISA and the LAF assay } \\
\hline \multicolumn{2}{|c|}{ Patient No. } & \multicolumn{2}{|c|}{$\begin{array}{c}\text { Reduction of } \\
\text { spontaneous } \\
\text { production } \\
\text { of IL-1 }\end{array}$} & \multicolumn{3}{|c|}{$\begin{array}{l}\text { Reduction of } \\
\text { IL-1 production } \\
\text { induced by IFN- } \gamma\end{array}$} \\
\hline & & \multicolumn{5}{|c|}{ \% of initial levels } \\
\hline \multicolumn{7}{|c|}{ ELISA } \\
\hline 1 & & \multicolumn{2}{|c|}{10} & \multicolumn{3}{|c|}{10} \\
\hline 3 & & \multicolumn{2}{|c|}{33} & \multicolumn{3}{|c|}{43} \\
\hline 4 & & \multicolumn{2}{|c|}{55} & \multicolumn{3}{|c|}{38} \\
\hline 5 & & \multicolumn{2}{|c|}{75} & \multicolumn{3}{|c|}{105} \\
\hline \multicolumn{7}{|c|}{ LAF bioassay } \\
\hline 2 & & \multicolumn{2}{|c|}{17} & \multicolumn{3}{|c|}{ Not done } \\
\hline \multicolumn{7}{|c|}{$\begin{array}{l}\text { B. Reduced levels of mRNA mesages for IL-1 } \beta \text { and TNF- } \alpha \text { as determined by } \\
\text { Northern blot and subsequent laser densitometry scanning analysis }\end{array}$} \\
\hline & \multicolumn{2}{|c|}{$\gamma$-Actin } & \multicolumn{2}{|c|}{ IL-1 $\beta$} & \multicolumn{2}{|c|}{ TNF- $\alpha$} \\
\hline Specimen & Area & $\begin{array}{l}\text { Rel. } \\
\text { area }\end{array}$ & Area & $\begin{array}{l}\text { Rel. } \\
\text { area }\end{array}$ & Area & $\begin{array}{l}\text { Rel. } \\
\text { area }\end{array}$ \\
\hline N1 & 2.39 & 16.8 & 1.84 & 23.7 & 0.83 & 17.2 \\
\hline $\mathrm{N} 2$ & 2.00 & 14.1 & 1.02 & 13.2 & 0.73 & 15.2 \\
\hline N3 & 1.76 & 12.4 & 0.76 & 9.8 & 0.77 & 16.0 \\
\hline RA I & 1.84 & 13.0 & 3.12 & 40.4 & 2.24 & 46.4 \\
\hline RA III & 2.30 & 16.2 & 0.87 & 11.3 & 0.25 & 5.2 \\
\hline HL-60 & 1.77 & 12.4 & 0.12 & 1.5 & 0.0 & 0.0 \\
\hline SF-Gran & 2.12 & 14.9 & 0.0 & 0.0 & 0.0 & 0.0 \\
\hline
\end{tabular}

Abbreviations: N, normal donor; RA I, RA patient, first leukapheresis; RA III, RA patient, third leukapheresis, both materials derived from patient no. 6; Rel., relative; SF-Gran, synovial fluid granulocytes (for original autoradiography, see Fig. 3).

cells. This notion is further supported by a reduced cell surface expression of markers of mature monocytes such as the CD14 and the DR antigens. In contrast, IFN- $\gamma$ and TNF- $\alpha$ receptor expression was not modulated after leukapheresis. Accordingly, the decreased responsiveness to IFN- $\gamma$ (neopterin and IL-1 $\beta$ ) after leukapheresis cannot be explained by a downregulation of IFN- $\gamma$ receptors. Of special interest was the observation that membrane expression of TNF- $\alpha$ receptors was very low ( 500 per cell) on freshly isolated RA monocytes and only detectable upon acid wash with no difference between the first and third leukapheresis. Moreover, in vitro culture of monocytes resulted in an apparently spontaneous upregulation of TNF- $\alpha$ receptors. Due to high levels of TNF production in first leukapheresis monocytes and, although reduced, ongoing TNF production in monocytes of the third leukapheresis, this finding was not unexpected. The data indicate a continuous receptor occupation/internalization by endogeneously produced TNF- $\alpha$, resulting in a downregulation of total TNF binding capacity. Our findings are in accordance with previous reports showing an antagonistic control of TNF receptor expression and TNF production of monocytes (44). Thus, it is conceivable that upon in vitro culture of the purified monocytes, TNF$\alpha$ production rapidly vanishes in the absence of appropriate stimuli, thereby allowing an increase in membrane expression of TNF receptors and recovery of TNF binding capacity.
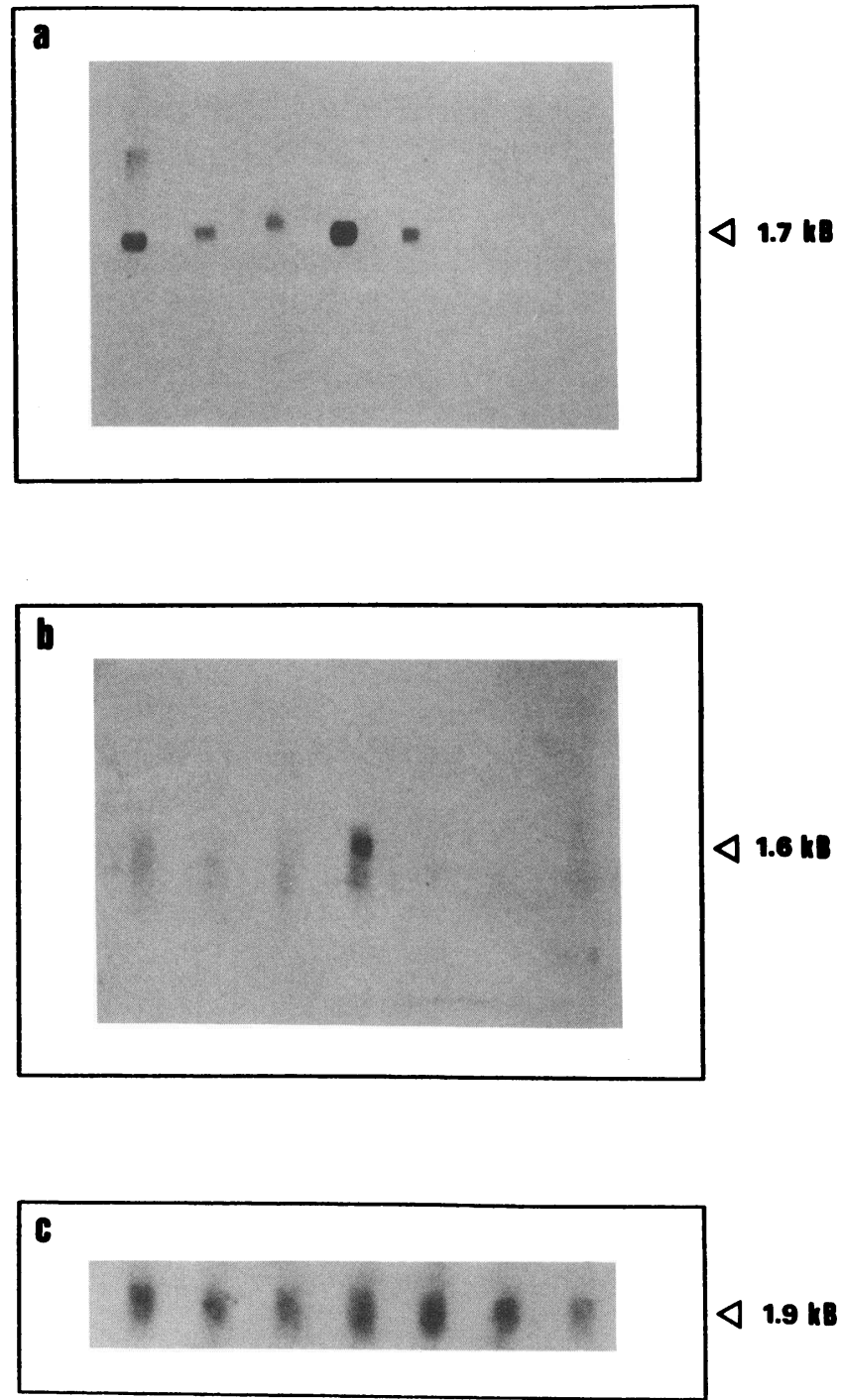

$\begin{array}{lllllll}1 & 2 & 3 & 4 & 5 & 6 & 7\end{array}$

Figure 3. Northern blot analysis of IL-1 $\beta$ and TNF- $\alpha$ genes in various cell populations. Total RNA $(25 \mu \mathrm{g})$ was denatured in formaldehyde, electrophoresed, and transferred to nylon membranes. Hybridizations were performed with purified insert probes of IL-1 $\beta(a)$, TNF- $\alpha(b)$, and $\gamma$-actin $(c)$ as control. Lanes 1-3: monocytes from healthy donors derived from a single leukapheresis. Lane 4: RA monocytes from first leukapheresis material. Lane 5: RA monocytes from third leukapheresis material. Both RA specimens were derived from patient 6 . Lane 6: HL-60 cell line. Lane 7: RA synovial fluid granulocytes. For semiquantitative analysis see densitometry results in Table IIB.

Our study also raises the question of what signals are responsible for monocyte activation in RA. One of the patients analyzed suffered from severe erosive RA, but had no detectable rheumatoid factors or immune complexes ( $\mathrm{Clq}$ binding and polyethylene glycol precipitation assay). Thus, at least in this patient it appears unlikely that these humoral factors are by themselves responsible for monocyte activation, which otherwise has been well substantiated (6). In a regular activation pathway, e.g., in infectious disease situations $(45,46)$, monocytes receive their stimulatory signals from $\mathrm{T}$ cells. However, while expression of phenotypical activation markers of $\mathrm{T}$ cells 
Table III. TNF- $\alpha$ and IFN- $\gamma$ Receptor Expression by RA Peripheral Blood Monocytes

\begin{tabular}{|c|c|c|c|c|c|c|}
\hline \multirow[b]{3}{*}{ Receptor } & \multirow[b]{3}{*}{ Cell source } & \multirow[b]{3}{*}{ Treatment } & \multicolumn{2}{|c|}{ RA 7} & \multicolumn{2}{|c|}{ RA 8} \\
\hline & & & \multicolumn{4}{|c|}{ Leukapheresis } \\
\hline & & & lst & 3 rd & $1 \mathrm{st}$ & 3 rd \\
\hline IFN- $\gamma-R$ & ex vivo & none & 1250 & 1400 & 2500 & 2550 \\
\hline IFN- $\gamma-\mathrm{R}$ & ex vivo & none & not done & $124^{*}$ & $142^{*}$ & $145^{*}$ \\
\hline \multirow[t]{2}{*}{ TNF- $\alpha-R$} & ex vivo & none & $\leq 50$ & $\leq 50$ & $\leq 50$ & $\leq 50$ \\
\hline & & $\mathrm{pH} 3$ & not done & not done & 500 & 500 \\
\hline TNF- $\alpha-R$ & $24 \mathrm{~h}$ in vitro & $\mathrm{pH} 3$ & not done & 2500 & not done & 1200 \\
\hline
\end{tabular}

Receptors per cell as determined by Scatchard plot analyses of ${ }^{125}$ I-IFN- $\gamma$ and ${ }^{125}$ I-TNF- $\alpha$ binding data. ${ }^{*}$ Specific fluorescence intensity as revealed by flow cytometry with the IFN- $\gamma$-specific mAb A6C5.

such as class II MHC antigens (47), IL-2 receptors (48), and the CD2R antigen (49) indicate $T$ cell activation, surprisingly low amounts of $\mathrm{T}$ cell-derived cytokines have been detected both on a protein and mRNA level in RA patients $(42,50)$. Further complexity is added to this problem by previous observations that leukapheresis may revert an anergic immunological state, resulting in enhanced $\mathrm{T}$ cell functions in certain RA patients $(51)$. In view of the evidence for decreased monocyte activation after leukapheresis, along with previous studies showing that activated RA monocytes contribute to the hyporesponsiveness of RA T cells (52), it is interesting to speculate that the reversion of anergy after leukapheresis is related to this change in monocyte behavior. Thus, while most pathogenetic pathways from the activated monocytes to tissue destructions become increasingly clear, there still remains the riddle how the whole process of the intense activation of the mononuclear phagocyte system is actually started.

\section{Acknowledgment}

We thank Dr. Ueli Gubler, Hoffmann-LaRoche Inc., Nutley, NJ for providing us with the plasmids for IL- $1 \beta$ and Dr. Arjun Singh, Genentech Inc., San Francisco, CA, for the kind gift of the TNF- $\alpha$ plasmid. The help of Dr. Karlheinz Weiner, Institute of Biochemistry, University of Erlangen-Nuremberg, in performing Laser scanning densitometry is greatly appreciated. This work was supported by the German Federal Ministry of Research and Technology (grants "Lymphokine" 01 ZU 8601, No. 41 and "Pathomechanismen" 01ZU8607, No. 31).

\section{References}

1. Burmester, G. R., P. Locher, B. Koch, R. J. Winchester, A. Dimitriu-Bona, J. R. Kalden, and W. Mohr. 1983. The tissue architecture of synovial membranes in inflammatory and non-inflammatory joint diseases. Rheumatol. Int. 3:173181.

2. Burmester, G. R., and J. R. Kalden. 1989. Monocytes in rheumatoid arthritis. In The Human Monocyte. M. Asherson and G. L. Zembala, editors. Academic Press, Ltd., London. 501-511.

3. Seitz, M., and W. Hunstein. 1985. Enhanced prostanoid release from monocytes of patients with rheumatoid arthritis and active lupus erythematodes. Ann. Rheum. Dis. 44:438-445.

4. Steven, M. M., S. E. Lennie, R. D. Sturrok, and C. G. Gemell. 1985. Enhanced bacterial phagocytosis by peripheral blood monocytes in rheumatoid arthritis. Ann. Rheum. Dis. 44:438-445.

5. Carter, S. D., J. T. Bourne, C. J. Elson, C. W. Hutton, R. Czudek, and P. A. Dieppe. 1984. Mononuclear phagocytes in rheumatoid arthritis: Fc-receptor expression by peripheral blood monocytes. Ann. Rheum. Dis. 43:424-429.

6. MacKinnon, S. K., and G. Starkebaum. 1987. Monocyte Fc receptor function in rheumatoid arthritis. Enhanced cell-binding of IgG induced by rheumatoid factors. Arthritis Rheum. 30:498-508.
7. Hopkins, S. J., and A. Meager. 1988. Cytokines in synovial fluid. II. The presence of tumor necrosis factor and interferon. Clin. Exp. Immunol. 73:88-92.

8. Firestein, G. S., J. M. Alvaro-Gracia, and R. Maki. 1990. Quantitative analysis of cytokine gene expression in rheumatoid arthritis. J. Immunol. 144:3347-3352.

9. Neopterins in clinical medicine. 1988. Lancet. March 5. $i(8584): 509-511$.

10. Reibnegger G., D. Egg, D. Fuchs, R. Günther, A. Hausen, E. R. Werner, and $H$. Wachter. 1986. Urinary neopterin reflects clinical activity in patients with rheumatoid arthritis. Arthritis Rheum. 29:1063-1070.

11. Fuchs, D., A. Hausen, G. Reibnegger, H. Reissigl, D. Schönitzer, T. Spira, and $\mathrm{H}$. Wachter. 1984. Urinary neopterin in the diagnosis of acquired immune deficiency syndrome. Eur. J. Clin. Microbiol. 3:70-71.

12. Karsh, J., D. G. Wright, J. H. Klippel, J. L. Decker, A. B. Deisseroth, and M. W. Flye. 1979. Lymphocyte depletion by continuous flow cell centrifugation in rheumatoid arthritis: clinical effects. Arthritis Rheum. 22:1055-1059.

13. Tenenbaum J., M. B. Urowitz, E. C. Keystone, I. L. Dwosh, and J. E. Curtis. 1979. Leukapheresis in severe rheumatoid arthritis. Ann. Rheum. Dis. 38:40-44.

14. Yeadon, C., and J. Karsh. 1983. Lymphapheresis in rheumatoid arthritis: the clinical and laboratory effects of limited course of cell depletion. Clin. Exp. Rheumatol. 1:119-124.

15. Arnett, F. C., S. M. Edworthy, D. A. Bloch, D. J. McShane, J. F. Fries, N. S. Cooper, L. A. Healey, S. R. Kaplan, M. H. Liang, H. S. Luthra, et al. 1988. The American Rheumatism Association 1987 revised criteria for the classification of rheumatoid arthritis. Arthritis Rheum. 31:315-324.

16. Ritchie, D. M., J. A. Boyle, J. M. McInnes, M. K. Jasani, T. G. Dalakos, P. Grievesen, and W. W. Buchanan. 1968. Clinical studies with an articular index for the assessment of joint tenderness in patients with rheumatoid arthritis. $Q . J$. Med. 147:393-406.

17. Platzer, E. 1991. Monozyten-Makrophagensystem. In Hämatologie. P. C. Ostendorf, editor. Urban und Schwarzenberg, München. 36-46.

18. Fischer, T., K. Wiegmann, H. Böttinger, K. Morens, G. R. Burmester, and K. Pfizenmaier. 1990. Regulation of IFN- $\gamma$-receptor in human monocytes by granulocyte-macrophage colony-stimulating factor. J. Immunol. 145:29142919.

19. Burmester, G. R., A. Dimitriu-Bona, S. J. Waters, and R. J. Winchester 1983. Identification of three major synovial lining cell populations by monoclonal antibodies directed to Ia antigens and antigens associated with monocytes/ macrophages and fibroblasts. Scand. J. Immunol. 17:69-81.

20. Burmester, G. R., B. Jahn, P. Rohwer, J. Zacher, R. J. Winchester, and J. R. Kalden. 1987. Differential expression of Ia antigen by rheumatoid synovial lining cells. J. Clin. Invest. 80:595-604.

21. Reinherz, E. L., P. C. Kung, G. Goldstein, R. J. Levey, and S. F. Schlossman. 1980. Discrete stages of human intrathymic differentiation: analysis of normal thymocytes and leukemic lymphocytes of T-cell lineage. Proc. Natl. Acad. Sci. USA. 77:1588-1594.

22. Gramatzki, M., V. Lauer, R. Burger, C. Huber, P. Rohwer, J. R. Kalden, and $F$. Henschke. 1989. Two newly developed anti-B cell antibodies with unusual staining characteristics. In Leukocyte Typing IV. Oxford University Press, New York.

23. Dimitriu-Bona, A., G. R. Burmester, S. J. Waters, and R. J. Winchester. 1983. Human mononuclear phagocyte differentiation antigens. I. Patterns of antigenic expression on surface of human monocytes and makrophages defined by monoclonal antibodies. J. Immunol. 130:145-152.

24. Aguet, M., and G. Merlin. 1987. Purification of human gamma interferon receptors by sequential affinity chromatography on immobilized monoclonal antireceptor antibodies. J. Exp. Med. 165:988-999.

25. Häupl, T., G. R. Burmester, G. Hahn, U. Feige, C. Rordorf-Adam, and J. R. Kalden. 1989. Differential immunological response of patients with rheumatoid arthritis towards two different Epstein-Barr virus strains: inhibition of interleukin-1 release by the B 95-8, but not the P3HR-1 virus strain. Rheumatol. Int. 9:153-160.

26. Feige, U., A. Karbowski, C. Rordorf-Adam, and A. Pataki. 1989. Arthritis induced by continuous infusion of hr-interleukin-la into the rabbit knee-joint. Int. J. Tissue React. 11:225-238.

27. Fischer, T., B. Thoma, P. Scheurich, and K. Pfizenmaier. 1990. Glycosylation of the human IFN- $\gamma$ receptor. J. Biol. Chem. 265:1710-1716.

28. Scheurich, P., G. Köbrich, and K. Pfizenmaier. 1989. Antagonistic control of tumor necrosis factor receptors by protein kinase A. J. Exp. Med. 170:947-959.

29. Chirgwin, J. M., A. E. Przybyla, R. J. McDonald, and W. J. Rutter. 1979. Isolation of biologically active ribonucleic acid from sources enriched in ribonuclease. Biochemistry. 18:5294-5299.

30. Goldberg, D. A. 1980. Isolation and partial characterisation of the Drosophila alcohol dehydrogenase gene. Proc. Natl. Acad. Sci. USA. 77:5794-5798.

31. Pfizenmaier, K., K. Wiegmann, P. Scheurich, M. Krönke, G. Merlin, M. Aguet, B. B. Knowies, and U. Ücer. 1988. High affinity human IFN- $\gamma$ binding capacity is encoded by a single receptor gene located in proximity to c-ros on human chromosome region $6 \mathrm{q} 16$ to $6 \mathrm{q} 22$. J. Immunol. 141:856-861.

32. Scheurich, P., B. Thoma, U. Ucer, and K. Pfizenmaier. 1987. Immunoreg- 
ulatory activity of recombinant human tumor necrosis factor (TNF)-alpha: induction of TNF receptors on human T cells and TNF-alpha mediated enhancement of T cell responses. J. Immunol. 138:1786-1790.

33. Saklatvala, J. 1986. Tumor necrosis factor a stimulates resorption and inhibits synthesis of proteoglycan in cartilage. Nature (Lond.). 322:547-550.

34. Reibnegger, G. D., D. Fuchs, R. Günther, A. Hausen, E. R. Werner, and H. Wachter. 1986. Urinary neopterin reflects clinical activity in patients with rheumatoid arthritis. Arthritis Rheum. 29:1063-1069.

35. Maerker-Alzer, G., O. Diemer, R. Strümper, and M. Rohe. 1986. Neopterin production in inflamed knee joints: high levels in synovial fluids. Rheumatol. Int. 6:151-154.

36. Burmester, G. R., G. Hahn, J. R. Kalden, and W. Kersten. 1988. Induction of neopterin release in monocytes from patients with rheumatoid arthritis by tumor-necrosis-factor alpha. In Pteridines and Biogenic Amines in Neuropsychiatry, Pediatrics and Immunology: Proceedings of the Second International Conference on Pteridines and related Biogenic Amines. R. A. Cevine, S. Milstien, D. M. Kuhn, and H. C. Curtius, editors. Lakeshore Publishing Company, Grosse Pointe, MI. 425-435.

37. Krause, A., H. Protz, and K. M. Goebel. 1989. Correlation between synovial neopterin and inflammatory activity in rheumatoid arthritis. Ann. Rheum. Dis. 48:636-640.

38. Peters, K. M., J. Dommaschk, R. Grundmann, M. Schaadt, and H. Schicha. 1990. Monitoring of tumor necrosis factor with neopterin. Arzneimittelforschung. 40:508-510.

39. Bitterlich, G., G. Szabo, E. R. Werner, C. Larcher, D. Fuchs, A. Hausen, G. Reibnegger, T. F. Schulz, J. Troppmair, H. Wachter, and M. P. Dierich. 1988 Selective induction of mononuclear phagocytes to produce neopterin by interferon. Immunobiology. 176:228-235.

40. Huber, C., J. R. Batchelor, D. Fuchs, A. Hausen, A. Lang, D. Niederwieser, G. Reibnegger, P. Swetly, J. Troppmair, and H. Wachter. 1984. Immune response associated production of neopoterin: release from macrophages primarily under control of interferon-gamma. J. Exp. Med. 160:310-318.

41. Henderson, D. C., J. Sheldon, P. Riches, and J. R. Hobbs. 1991. Cytokine induction of neopterin production. Clin. Exp. Immunol. 83:479-482.

42. Firestein, G. S., N. J. Zvaifler. 1987. Peripheral blood and synovial fluid monocyte activation in inflammatory arthritis: low levels of synovial fluid and synovial tissue interferon suggest that $\gamma$-interferon is not the primary macrophage activating factor. Arthritis Rheum. 30:864-874.
43. Brennan, F. M., D. Chantry, A. M. Jackson, R. N. Maini, and M. Feldmann. 1989. Cytokine production in culture by cells isolated from the synovial membrane. J. Autoimmun. 2(Suppl.):177-186.

44. Scheurich, P., G. Kobrich, and K. Pfizenmaier. 1989. Antagonistic control of tumor necrosis factor receptors by protein kinases $\mathrm{A}$ and $\mathrm{C}$ : enhancement of TNF receptor synthesis by protein kinase A and transmodulation of receptors by protein kinase C. J. Exp. Med. 170:947-958.

45. Murray, H. W., J. I. Stern, K. Welte, B. Y. Rubin, S. M. Carriero, and C. F. Nathan. 1987. Experimental visceral leishmaniasis production of interleukin-2 and interferon-gamma, tissue immune reaction, and response to treatment with interleukin-2 and interferon-gamma. J. Immunol. 138:2290-2297.

46. Gould, C. I., and G. Sonnenfeld. 1987. Effect of treatment with Interferon-gamma and concanavalin A on the course of infection of mice with Salmonella typhimurium strain LT-2. J. Interferon. Res. 7:635-639.

47. Burmester, G. R., D. T. Y. Yu, A. M. Irani, H. G. Kunkel, and R. J. Winchester. 1981. Characterization of Ia $+\mathrm{T}$ cells in patients with rheumatoid arthritis. Arthritis Rheum. 24:1370-1376.

48. Burmester, G. R., B. Jahn, M. Gramatzki, J. Zacher, and J. R. Kalden. 1984. Activated $T$ cells in vivo and in vitro: different phenotypic expression of Tac and Ia antigens in patients with inflammatory joint diseases and normal in vitro activated T cells. J. Immunol. 133:1230-1234.

49. Potocnik A. J., H. Menninger, S. Y. Yang, K. Pirner, A. Krause, G. R. Burmester, B. M. Bröker, P. Hept, G. Weseloh, H. Michels, et al. 1991. Expression of the CD2 activation epitope T11-3 (CD2R) on T cells in rheumatoid arthritis, systemic lupus erythematosus, ankylosing spondylitis, and Lyme disease: phenotypic and functional analysis. Scand. J. Immunol. 34:351-358.

50. Firestein, G. S., W. D. Xu, K. Townsend, D. Broide, J. Alvaro-Gracia, A Glasebrook, and N. J. Zvaifler. 1988. Cytokines in chronic inflammatory arthritis. I. Failure to detect T cell lymphokines (interleukin 2 and interleukin 3 ) and presence of macrophage colony-stimulating factor (CSF-1) and a novel mast cell growth factor in rheumatoid synovitis. J. Exp. Med. 168:1573-1586.

51. Wahl, S. M., R. L. Wilder, I. M. Katona, L. M. Wahl, J. B. Allen, I. Scher, and J. L. Decker. 1983. Leukapheresis in rheumatoid arthritis. Association of clinical improvement with reversal of anergy. Arthritis Rheum. 26:1076-1084.

52. Flescher, E., T. L. Bowling, A. Ballester, R. Houk, and N. Talal. 1989. Increased polyamines may downregulate interleukin 2 production in rheumatoid arthritis. J. Clin. Invest. 83:1356-1362. 